«Системні технології» 4 (129) 2020 «System technologies»

DOI 10.34185/1562-9945-4-129-2020-07

УДК 711.8

О.М. Назаренко, В.І. Доненко, I.А. Назаренко

\title{
СИСТЕМА ОПЕРАЦЙНОГО ВІДНОВЛЕННЯ ПРІСНОГО РЕСУРСУ ВОДОЙМИЩ МІСТА
}

Анотація. Екосистеми міст складаються з дивовижних взаємодій живих організмів і абіотичного середовища, створюючи динамічні цикли поживних речовин і енергії. Здатність людини витісняти і формувати природні процеси покращилася, але громада продовжує залежати від товарів і послуг, що надаються екосистемами. Структура екосистемних послуг уточнює зв'язок між добробутом людини та функцією екосистеми. Екосистемні послуги надаються екосистемі для підтримки добробуту громади. Технологія екосистемної послуги створює зворотний зв'язок, який сприяє як екосистемі, так $і$ благополуччю громади. У цьому контексті очевидно, що ризики для природних ресурсів подібні ґрунтам $і$ водним ресурсам мають прямі наслідки для громади.

Ключові слова: повторні води, акумулювання, кавітаційний генератор, завислі речовини, механічна ерозія, водний баланс, температура, система.

Дослідження поповнення водного балансу міста важливо, особливо в південних регіонах України, де засухи порушують стабільність процесів та приводять до соціального напруження в громаді.

Матеріали і методи досліджень. В роботі продовжується гідрологічні дослідження та математичні пошукування таких вчених, як Прандтль Д., Хосокава Т., Івасакі М., Рябенко О.А., Цхай А.А., Епоян С.М., Пантелят Г.С., Малько В.Г., Кравчук С.М., Стольберг Ф.З., Карагяур А.С. Традиційно гідрологічні вимірювання проводяться в природних умовах, автори пропонують використання техногенних потоків для підвищення енергоефективності системи водопостачання.

Мета та завдання. Дана робота виконувалась у відповідності до вимог надійності систем водопостачання та забезпечення сталості економічного розвитку міст. Враховані вимоги забезпечення сталості розвитку прісноводних ресурсів програми «Інтегроване управління водними ресурсами».

(c) Назаренко O.M., Доненко B.I., Назаренко I.A., 2020 
«Системні технології» 4 (129) 2020 «System technologies»

Результати дослідження. Структура екосистемних послуг $\epsilon$ iнструментом, який можна використовувати в межах стратегічного керування водоспоживанням міста та регулювання басейнів річок. Інструмент допомагає регуляторам оцінити види землекористування та заходи зменшення або заборони техногенного впливу на розвиток громади. Підхід екосистемних послуг не має залучення грошової оцінки, але шляхом створення обмежень, він розширює інструменти, що знаходяться у розпорядженні регулятора [11]. Обговорення наслідків техногенних сценаріїв різними групами експертів та зацікавлених сторін, може бути достатньо для знаходження компромісів при різних сценаріях використання територій.

Дослідження ризиків дебалансу водосховища важливо для розуміння меж технологічної схеми та визначення інструментарію стабілізації басейну міста. При випуску вода проходить локальне кавітаційне очищення та в разі необхідності хімічне втручання для корегування рН (промислові райони) (табл 1).

Висновки. В роботі класифіковані промислові та аграрні стоки по доцільності відновлення. Виконано дослідження просочення різних типів грунтів (від 1.11 до 0,05 cм/годину) для живлення аграрних зон кондиційованими повторними водами. Розроблена система відновлення повторних вод, що компенсує до $32 \%$ дебалансу водного басейну.

Таблиця 1

Показники умовно чистої води при обробці кавітаційним генератором

\begin{tabular}{|l|c|}
\hline \multicolumn{1}{|c|}{ Показник } & Кут 5 \\
\hline Жорсткість початкова, мг-екв/л & 4,21 \\
\hline Жорсткість остаточна, 1 цикл, мг-екв/л & 3,3 \\
\hline Жорсткість остаточна, 7 цикл, мг-екв/л & 2,88 \\
\hline Лужність початкова, мг-екв/л & 3,2 \\
\hline Лужність остаточна, 1 цикл, мг-екв/л & 2,42 \\
\hline Лужність остаточна, 7 цикл, мг-екв/л & 2,03 \\
\hline рН початкова & 7,4 \\
\hline рН 7 цикл & 6,4 \\
\hline Солевміст, мг/л & 275 \\
\hline Солевміст, 1 цикл, мг/л & 221 \\
\hline Солевміст, 7 цикл, мг/л & 238 \\
\hline
\end{tabular}


«Системні технології» 4 (129) 2020 «System technologies»

Результати дослідження доводять можливості відтворення хімічних показників якості води на $1 . . .3$ циклах). При збільшенні кількості циклів очищення до 7, жорсткість зменшується до 2,88 мг-екв/л, лужність дорівнює 2,03 мг-екв/л, підвищується солевміст до 238 мг/л.

Новоутворення озону при температурі $(105 . .107)^{\circ} \mathrm{C}$ (кут 5градусів), який в ході реакції багаторазово взаємодіє в умовах турбулентної реакції з молекулами забруднювача та знешкоджує їх в стадії адсорбції.

Пропонується дистанційне вимірювання жорсткості, лужності води, $\mathrm{pH}$, солевмісту та концентрацію можливих токсичних речовин за допомогою електронного блоку Arduino. При виникнення ризиків в збірних водоводах система дає сигнал та надає гнучку хімічну допомогу в районних насосних станціях.

Більш справедливо для прийняття важливих рішень залучення експертів зовнішніх та наукового середовища для моделювання сценаріїв водних ризиків та ступіню техногенного навантаження на район та регіон.

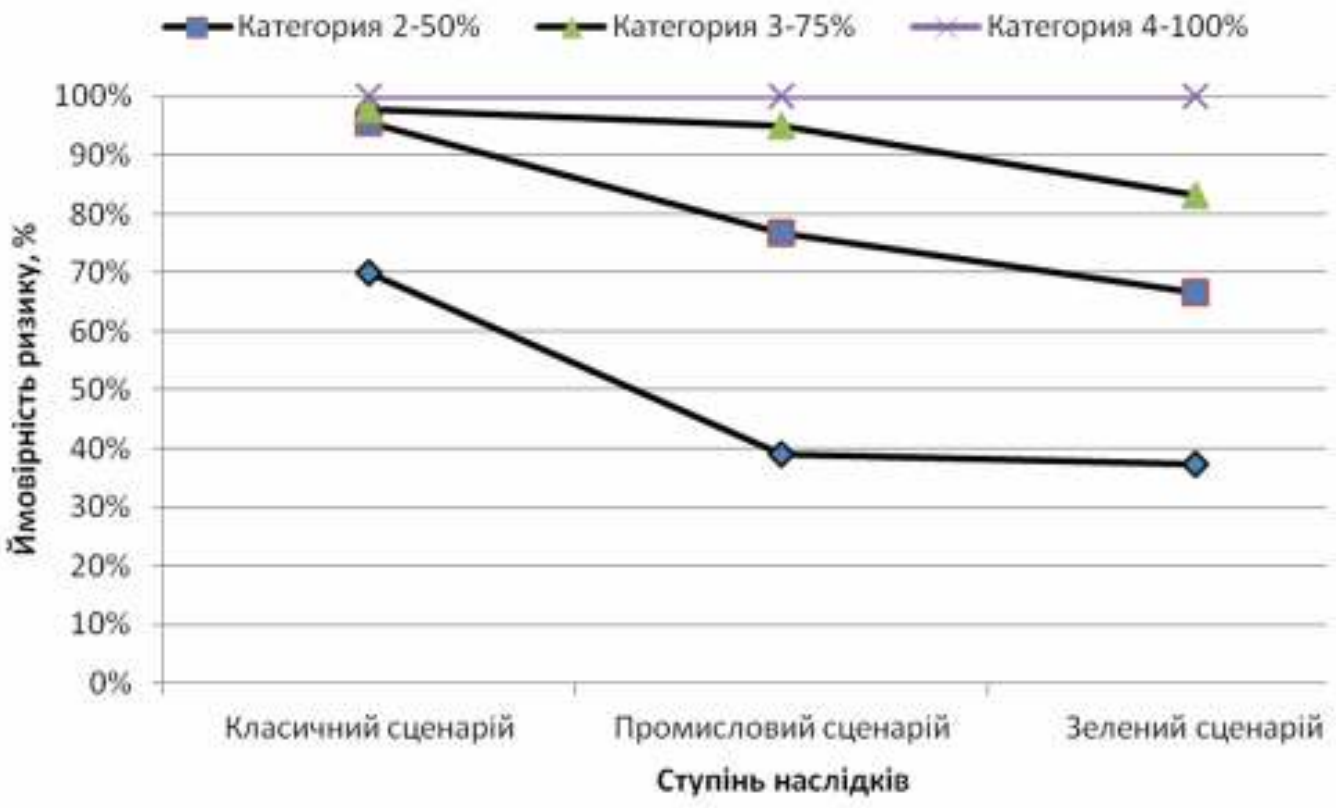

Рисунок 1 - Наслідки ризиків водопостачання по сценаріях 
«Системні технології» 4 (129) 2020 «System technologies»

Дослідження використання умовно чистих вод виявили глибину просочення вологи в Запорізькій області до 18 см, в Дніпропетровській області до 36 см.

Досліджувані властивості грунту спиралися на текстурні індикатори пород-пісок, глину, мул, кварцевий пісок, а також на обсяг ділянки, точку збору, концентрації речовин, ємність катіонообміну. Один з більш чутливих параметрів грунту - насичена гідравлічна провідність. Виділення грунтів на два класи на основі вмісту глини, має передбачуване відношення більше 40 відсотків. Розроблено рівняння гідравлічної провідності глини:

$$
K_{b}=0,0066 \times \exp \left(\frac{244}{\% \text { озавислих }}\right)
$$

Для грунтів з глиною менше 40\%, співвідношення для Кь включає два параметри для змісту піску :

$$
K_{b}=-0,265+0,0866 C_{\text {nicky }}+11,46 C^{-0,75}
$$

Дослідження продемонструвало успішне прогнозування моделі 3 використанням адаптації рівняння змішаної суміші для 1,5 годинного проміжка часу, в сценарії умовно брудних та умовно чистих вод агроланшафту.

Розрахована питома вологість грунтів Запорізбкої області в межах 0,5 cм/годину, Днепропетровської області - 0,9см/годину. Польові дослідження гідрологічних параметрів водоймищ надали рівняння потоку прісної поверхневої рідини:

$$
\left(\rho_{u}\right)_{x}=\rho_{u}+\frac{\partial}{\partial x}(\rho u) d x+\frac{\partial^{2}}{\partial x^{2}}(\rho u) \frac{\partial Q^{2}}{r}+\ldots+\left[\rho u+\frac{\partial}{\partial x}(\rho u) d x\right] d z d t n
$$

При дослідах кондиціювання чистих та брудних вод завислі речовини будуть відсепаровані в кавітаційному устаткуванні:

$$
m(t+d t)=\left(\rho+\frac{\partial \rho}{\partial t}\right) d x d y d z
$$


«Системні технології» 4 (129) 2020 «System technologies»

$$
\begin{gathered}
d m=\left(\rho+\frac{\partial \rho}{\partial t} d t\right) d x d y d z-\rho d x d y d z \\
d m=\frac{\partial \rho}{\partial t} d t d x d y d z
\end{gathered}
$$

Коефіцієнт дифузії мас визначаємо:

$$
\begin{array}{r}
-D_{c}\left(\frac{\partial^{2} c}{\partial x^{2}}+\frac{\partial^{2} c}{\partial y^{2}}+\frac{\partial^{2} c}{\partial z^{2}}\right)=d x d y d z d t \\
{\left[\frac{\partial}{\partial x}(u c)+\frac{\partial}{\partial y}(v c)+\frac{\partial}{\partial z}(w c)\right] d x d y d z d t=\frac{\partial c}{\partial t} d x d y d z d t} \\
\frac{\partial c}{\partial t}=D_{c} \nabla^{2} c
\end{array}
$$

збереження маси потоку водоймища

Багатофункціональна концепція використовує систему для підтримки експертів у розвитку зв'язків між балансом системи водопостачанням та численними перевагами інтеграції (табл. 2).

Результати свідчать, що умовно чисті води в металургійній промисловості мають пересичення по карбонату кальцію до 68,41 разів, та

\begin{tabular}{|c|c|c|c|c|c|c|}
\hline & $\begin{array}{l}\text { Жорсткість } \\
\text { мг-екв/дм }{ }^{3}\end{array}$ & $\begin{array}{c}\text { Лужність } \\
\text { мг- } \\
\text { кВ } / \text { дм }\end{array}$ & $\begin{array}{c}\text { Солевміст } \\
\text { мг/л }\end{array}$ & $\begin{array}{c}\mathrm{Ns} \\
\mathrm{CaCo}_{3}\end{array}$ & $\begin{array}{c}\mathrm{Ns} \\
\mathrm{MgOH}\end{array}$ & $\begin{array}{c}\mathrm{N} \\
\text { цикл }\end{array}$ \\
\hline $\begin{array}{c}\text { Легка проми- } \\
\text { словість }\end{array}$ & 7,5 & 6,8 & 570 & 27,5 & 119 & 35 \\
\hline $\begin{array}{c}\text { Металургійна } \\
\text { (у.ч.) }\end{array}$ & 12 & 11,2 & 630 & 68,41 & 120 & 42 \\
\hline $\begin{array}{c}\text { Металургійна } \\
\text { (у.бр.) }\end{array}$ & 14 & 9,8 & 1120 & 78,19 & 261 & 78 \\
\hline Харчова & 8,1 & 6,8 & 610 & 23,87 & 14 & 12 \\
\hline
\end{tabular}
по гідроксиду магнію до 120 разів. Потрібно 42 цикли роботи кавітаційного генератору для доведення ресурсу до питної якості.

Таблиця 2

Визначення переваг седиментаційної кавітації 
«Системні технології» 4 (129) 2020 «System technologies»

Аналогічно по умовно брудним водам досліди надали результати пересичення карбонату кальцію 78,19 разів, по магнію 261 разів. В цьому випадку практично можливо довести ресурсу до питної якості при 78 циклах роботи генератору, до 248 годин, тобто на протязі 10 діб.

Пропонуєма система попередження ризику водного середовища всебічно аналізує стан навколишнього середовища та дає попереджувальні сигнали (поодинокі індикатори та сумарні індекси).

Оцінка стану регіонального екологічного розвитку складається 3 п’яти операцій:

1) Загальна операція управління басейном

Представлення ризику водного басейну показано на візуальному інтерфейсі, включаючи загальну регіональну ситуацію, стан річки та зону водного буферу, що надає користувачам інформацію про географічне положення, гідрологію та метеорологію, стан та розташування водних функціональних зон.

2)Операція оцінки водного середовища

Цей процес оцінює зміни якості води в кожному перетині басейну 3 часом, своєчасно досліджує правила розподілу води, генерує діаграми розподілу основних категорій користувачів, класифікованих за основними показниками забруднення у вибраних перетинах моніторингу, обчислює індикаторні коефіцієнти перетинів.

3) Операція управління відходами

Інформація про водо відводи всіх річок, обчислюючи надлишкову ємність функціональних зон та кількість забруднюючих речовин. Модуль може імітувати концентрацію забруднюючих речовин на ділянці водозабору нижче за течією після їх деградації та дифузії та відстань впливу забруднюючих речовин.

4) Поступова прогресія попередження ризику водного середовища На основі аналізу атмосферних опадів та попиту на воду процес поєднує з даними про кількість води, рівень води та якість води; визначити стан місцевих водних ресурсів та ступінь забруднення водних об’єктів. 
«Системні технології» 4 (129) 2020 «System technologies»

Потім він прогнозує можливі резерви живлення басейну та здійснює раннє попередження водного середовища (табл..3).

В ході досліджень рекреаційного озера міста визначено турбулентну в'язкість за допомогою дворівневої моделі турбулентності кінетичної

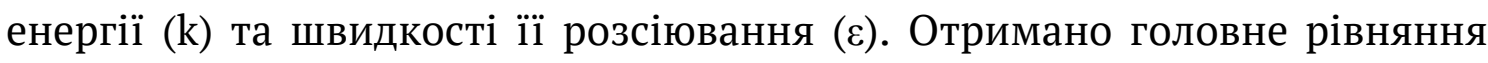
кінетичної енергії турбулентності та розсіювання швидкості потоку для практичного застосування до стандартної k- $\varepsilon$ моделі та низьких значень Рейнольдса:

$$
\begin{array}{r}
\frac{\partial}{\partial x_{1}}\left(\rho_{u i} k\right)-\frac{\partial}{\partial x_{i}}\left(\frac{\mu_{e}}{\sigma_{k}} \frac{\partial k}{\partial x_{i}}\right)=G-p(\varepsilon+D) \\
\frac{\partial}{\partial x_{1}}\left(\rho_{u i} \varepsilon\right)-\frac{\partial}{\partial x_{i}}\left(\frac{\mu_{e}}{\sigma_{\varepsilon}} \frac{\partial \varepsilon}{\partial x_{i}}\right)=\left(C_{1} f_{1} G-C_{2} f_{2} \rho \varepsilon\right) \frac{\varepsilon}{k}+\rho E
\end{array}
$$

Турбулентна в'язкість $\mu \mathrm{t}$ потоку:

$$
\mu_{t}=c \mu f \mu \rho k / 2
$$

У прямих річках, при джерелі забруднення в центрі річки, бічна відстань:

$$
Л_{\mathcal{M}}=0,213 \times u \times B^{2} / E y
$$

Джерело забруднення на березі річки:

$$
Л_{\mathcal{M}}=0,716 \times u \times B^{2} / E y
$$

де Лм - поперечна довжина перемішування забруднюючих речовин (м);

$\mathrm{u}$ - середня швидкість річкового потоку (м/с);

В - середня ширина русла річки (м);

Еу - коефіцієнт бічної дисперсії $\left(\mathrm{M}^{2} / \mathrm{c}\right)$. 
«Системні технології» 4 (129) 2020 «System technologies»

Таблиця 3

Сигнал попередження забруднення басейну річки

\begin{tabular}{|c|c|c|c|}
\hline \multicolumn{4}{|c|}{ Попередження ризику } \\
\hline Річка & Індикатор & Перетин & Значення \\
\hline Тип забруднювача & Свинець & Концентрація & 0,5 \\
\hline $\begin{array}{c}\text { Біодеградація забру- } \\
\text { днювача }\end{array}$ & Так & Не біодеградація & $\mathrm{Hi}$ \\
\hline Позиціонування & $\mathrm{A} 2$ & Вплив ситуації & $\mathrm{A} 2$ \\
\hline Засуха & $\geqslant 30$ & & Ключові мі- \\
& & & ста \\
\hline Засуха & $<20$ & & регіон \\
\hline Засуха & $<10$ & & Країна \\
\hline Засуха & $<3$ & & А \\
\hline Трансфер & А3 & Економічні втрати & скиду \\
\hline Оцінка трансферу & $\geqslant 10000$ & Пряма економічна & млн \\
\hline Оцінка трансферу & 8000 & внші ситуації & \\
\hline Оцінка тренсферу & 1000 & & \\
\hline Оцінка трансферу & 100 & & \\
\hline Оцінка трансферу & $<3$ & & \\
\hline Ступінь ризику & ІІІ & Середній & \\
\hline
\end{tabular}

При батиметричних розрахунках рівня води річки Дніпро (сток води) розроблено модель нестабільної якості води:

$$
C(x, y, t)=\frac{M}{H 4,24 \pi \tau \sqrt{E x E y}} \exp \left[\frac{-(x-u t)^{2}}{4 E x t}-\frac{y^{2}}{4 E y \tau}-2 k t\right]+C h
$$

де М - витік забруднюючих речовин (г);

Н - глибина ділянки річки (м);

$\mathrm{t}$ - час прогнозування;

$\mathrm{Ch}$ - початкова концентрація забруднюючих речовин у річці (мг / л); 66 
«Системні технології» 4 (129) 2020 «System technologies»

Еx - коефіцієнт поздовжньої дифузії (м2)/ с);

К - коефіцієнт деградації забруднюючих речовин (л / с);

x - вертикальна відстань між точками скидання до споживання (м);

у - поперечна відстань від точки скидання до забору води (м).

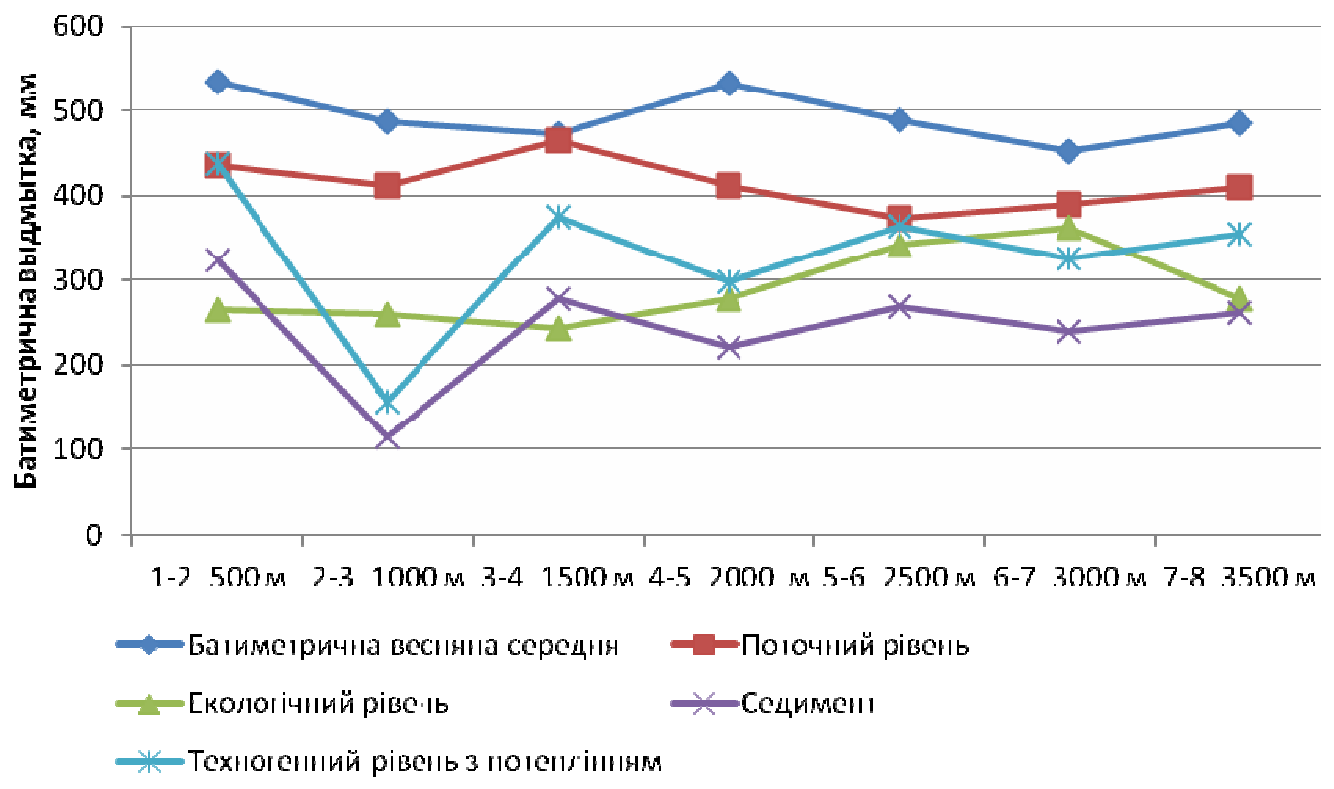

Рисунок 2 - Рівні доступної води в різних перетинах річки Дніпро (промисловий сегмент)

Розроблена математична модель седиментаційної моделі очистки виглядає:

$$
\mathrm{Y}=46,062-7,172 \mathrm{x}_{2}-16,745 \mathrm{x}_{3}-25,898 \mathrm{x}_{2}^{2}+2,738 \mathrm{x}_{3}^{2}+14,137 \mathrm{x}_{2}{ }^{*} \mathrm{X}_{3}
$$

де $\mathrm{X}_{1}$ - жорсткість води, мг-екв/л;

$\mathrm{X}_{2}$ - продуктивність процесу, \%, У - кількість циклів - 15-74 рази.

Результати рівняння оброблено по статистичним критеріям Кохрена, Стьюдента та Фішера, які показали адекватну математичну модель та можливість впровадження у народному господарстві. 
«Системні технології» 4 (129) 2020 «System technologies»

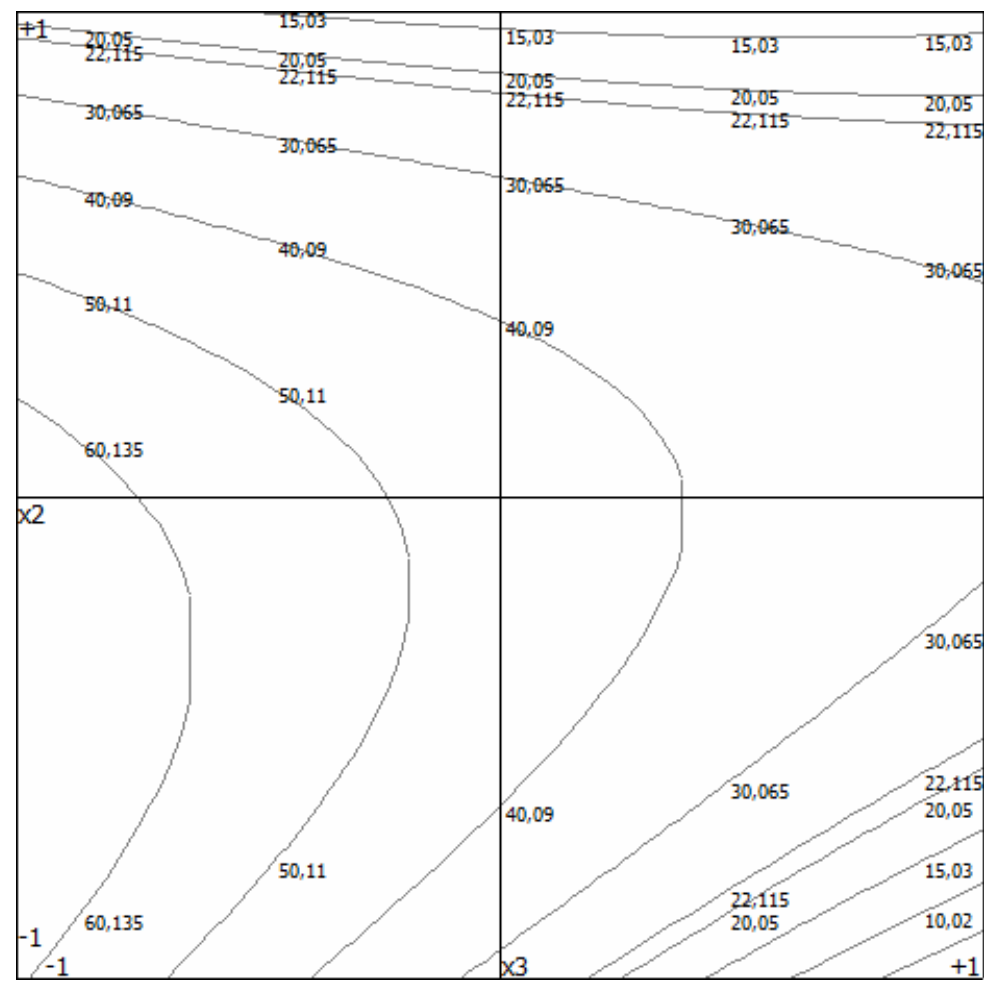

Рисунок 3 - Діаграма ліній рівного уровня

Висновки. В роботі класифіковані промислові та аграрні стоки по доцільності відновлення. Виконано дослідження просочення різних типів грунтів (від 1.11 до 0,05 cм/годину) для живлення аграрних зон кондиційованими повторними водами. Розроблена система відновлення повторних вод, що компенсує до $32 \%$ дебалансу водного басейну.

\section{ЛІТЕРАТУРА / ЛИТЕРАТУРА}

1. Jorgensen S.E. Handbook of Ecologica lModels Used in Ecosystem and Environmental Management/CRC Press University Denmark.Copenhagen, $2011.600 \mathrm{p}$.

2. Назаренко О.M. Ризик менеджмент водокористувачів річки Дніпро:монографія/ Запоріжжя: СТС Групп, 2018. 208 с.

3. Олійник О. Я., Айрапетян Т. С. Розрахунок кисневого режиму при біологічному очисщенні стічних вод в аеротенках-змшувачах з закріпленим і зваженим біоценозом // Науковий вісник будівництва. - Харків: ХНУБА, ХОТВ АБУ.-2019.-№1(94).- С.187-191.

4. Утеплення, ремонт та реконструкція плоских покрівель цивільних будівель: посібник / Авраменко Ю. О., Лещенко М. В., Магас Н. М. [та ін.]; за ред. О. В. Семка. - Полтава: ТОВ «Астрая», 2017. - 238 с. 
«Системні технології» 4 (129) 2020 «System technologies»

5.Marker B.A., Breure A.M., Zechmeister H.G. Bioindicators and biomonitors. Principles, concepts and application. Handbook/ElsevrierScienceLtd. 2003. $1017 \mathrm{p}$.

6. Ремонт и эксплуатация рулонных кровель: Практическое пособие для работников ЖКХ / Н.М. Вавуло, А.Е. Харьковский, Р.Ф. Зарипов, О.Л. Рогачевский, В.А. Желнинский, И.М. Дегтярев, А.Н. Лычиц, Д.А. Фисюренко. - М.; СПб.: ООО «АТМ», 2011. - 86 с.

7. Syvitski J., Cohen S., Miara A., Best J. River temperature and the thermaldynamic transport of sediment. Global and Planetary Change. Volume 178, 7/2019, p. 168-183.

8. Elgueta M., Astaburuaga M., Hassan A. Sediment storage, partial transport, and the evolution of an experimental gravel bed under changing sediment supply regimes Geomorphology. Volume 330, 4/2019, p. 1-12.

9. Kehui Xu, Samuel J., Bentley J., Day W., Freeman A. A review of sediment diversion in the Mississippi River Deltaic Plain. Estuarine, Coastal and Shelf Science. 5/2019, 235p.

10. Kuprienko P., Lapowska S., Kuprienko N, 2017. Nanomodified natural aluminum silicates in technology treatment of industrial waste and the production of building materials. Underwater technologies, Vol.05, 74-83.

11. Яркин В.А. Определение эффективности работы перегородчатого смесителя коридорного типа усовешенствованной конструкции /В.А. Яркин, С.М. Эпоян, Г.И. Сухоруков// Науковий вісник будівництва. - Харків: ХНУБА, ХОТВ АБУ. - 2018.-Т.91, №1.- С.210-214.

12. Эпоян С.М. Метод повышения эффективности смешения природной воды с реагентом и методика проведения исследований / С.М. Эпоян, Г.И. Сухоруков, В.А. Яркин// Науковий вісник будівництва. - Харків: ХНУБА, ХОТВ АБУ.-2016.-№1(83).- С.187-193.

13. Проскурнин О. А., Захарченко Н. И., Капанина О. И. Нормирование состава теплообменных сточных вод // Науковий вісник будівництва. Харків: ХНУБА, ХОТВ АБУ.-2018.-№4(92).- С.226-231.

14. ДБН В.2.6-220:2017 Покриття будівель і споруд. [Текст]:-К.: Міністерство регіонального розвитку та будівництва України, 2017. -43 с. 15. ДСТУ-Н Б В.1.2-18:2016. Настанова щодо обстеження будівель і споруд для визначення та оцінки їх технічного стану. - К.: ДП «УкрНД-НЦ», 2017. - 45 c. 


\section{«Системні технології» 4 (129) 2020 «System technologies»}

\section{REFERENCES}

1. Jorgensen S.E. Handbook of Ecologica IModels Used in Ecosystem and Environmental Management/CRC Press University Denmark.Copenhagen, $2011.600 \mathrm{p}$.

2. Nazarenko O.M. Ryzyk menedzhment vodokorystuvachiv richky Dnipro[Risk management of the Dnieper River water users]:monohrafiia/ Zaporizhzhia: STS Hrupp, 2018. 208 s.

3. Oliinyk O. Ya., Airapetian T. S. Rozrakhunok kysnevoho rezhymu pry biolohichnomu ochysshchenni stichnykh vod $\mathrm{v}$ aerotenkakh-zmshuvachakh z zakriplenym $\mathrm{i}$ zvazhenym biotsenosom. [Calculation of the oxygen regime at biological sewage treatment in aerotanks-mixers with fixed and weighted biocenosis zom] // Naukovyi visnyk budivnytstva. - Kharkiv: KhNUBA, KhOTV ABU.-2019.-№1(94).pp.187-191.

4.Uteplennia, remont ta rekonstruktsiia ploskykh pokrivel tsyvilnykh budivel: posibnyk [Insulation, repair and reconstruction of flat roofs of civilian buildings] / Avramenko Yu. O., Leshchenko M. V., Mahas N. M. za red. O. V. Semka. - Poltava: TOV «Astraia», 2017. - 238 s.

5.Marker B.A., Breure A.M., Zechmeister H.G. Bioindicators and biomonitors. Principles, concepts and application. Handbook / ElsevrierScienceLtd. 2003. $1017 \mathrm{p}$.

6. Remont y эkspluatatsyia rulonnykh krovel: Praktycheskoe posobye dlia rabotnykov ZhKKh

[Repair and operation of rolled roofs: A practical manual for housing and communal services workers] / N.M. Vavulo, A.E. Kharkovskyi, R.F. Zarypov, O.L. Rohachevskyi, V.A. Zhelnynskyi, Y.M. Dehtiarev, A.N. Lichyts, D.A. Fysiurenko. - M.; SPb.: OOO «ATM», 2011. - 86 s.

7. Syvitski J., Cohen S., Miara A., Best J. River temperature and the thermaldynamic transport of sediment. Global and Planetary Change. Volume 178, 7/2019, pp. 168-183.

8. Elgueta M., Astaburuaga M., Hassan A. Sediment storage, partial transport, and the evolution of an experimental gravel bed under changing sediment supply regimes Geomorphology. Volume 330, 4/2019, pp. 1-12.

9. Kehui Xu, Samuel J., Bentley J., Day W., Freeman A. A review of sediment diversion in the Mississippi River Deltaic Plain. Estuarine, Coastal and Shelf Science. 5/2019, pp.235-241. 
«Системні технології» 4 (129) 2020 «System technologies»

10. Kuprienko P., Lapowska S., Kuprienko N, 2017. Nanomodified natural aluminum silicates in technology treatment of industrial waste and the production of building materials. Underwater technologies, Vol.05, pp.74-83.

11. Yarkyn V.A. Opredelenye effektyvnosty raboty perehorodchatoho smesytelia korydornoho typa usoveshenstvovannoi konstruktsyy [Determination of efficiency of work of a partition mixer of a corridor type of the advanced design ] ] /V.A. Yarkyn, S.M. Epoian, H.Y. Sukhorukov// Naukovyi visnyk budivnytstva. - Kharkiv: KhNUBA, KhOTV ABU. - 2018.-T.91, №1.pp.210-214.

12. Epoian S.M. Metod povyshenyia effektyvnosty smeshenyia pryrodnoi vody $\mathrm{s}$ reahentom y metodyka provedenyia yssledovanyi [The method of increasing the efficiency of mixing natural water with the reagent and the method of research] / S.M. Epoian, H.Y. Sukhorukov, V.A. Yarkyn// Naukovyi visnyk budivnytstva. - Kharkiv: KhNUBA, KhOTV ABU.-2016.-№1(83).- pp.187-193.

13. Proskurnyn O. A., Zakharchenko N. Y., Kapanyna O. Y. Normyrovanye sostava teploobmennykh stochnykh vod [Background of the heat exchange composition] // Naukovyi visnyk budivnytstva. - Kharkiv: KhNUBA, KhOTV ABU.-2018.-No4(92).- pp..226-231.

14. DBN V.2.6-220:2017 Pokryttia budivel i sporud. [DBN B.2.6-220: 2017 Covering of buildings and structures]: - K.: Ministerstvo rehionalnoho rozvytku ta budivnytstva Ukrainy, 2017. - 43 p.

15. DSTU-N B V.1.2-18:2016. Nastanova shchodo obstezhennia budivel i sporud dlia vyznachennia ta otsinky yikh tekhnichnoho stanu. [DSTU-N B B.1.2-18: 2016. Guidelines for inspection of buildings and structures to determine and evaluate their technical condition] - K.: DP «UkrND-NTs», 2017. $45 \mathrm{p}$.

Received 27.02.2020. Accepted 02.03.2020.

Система операционного восстановления пресного ресурса водоемов города

Работа проектирует систему производственных компонентов городской инфраструктуры для создания энергоэффективного города. Исследованы гидравлические, гидрологические, теплообменные процессы взаимодействия водной структуры и элементов очистных конструкций для центробежного осаждения взвешенных веществ. Определены технологический цикл восстановления повторной воды и количество циклов кавитационного генератора управляемого кондиционирования условно чистых и грязных вод. Категоризированы потенциальные утечки промышленных вод с целесообразностью восстановления. Получены образцы экспериментальных осадков для нужд строительного хозяйства при рабочих и сверхкритических режимах работы технологической цепочки. 


\section{«Системні технології» 4 (129) 2020 «System technologies»}

\section{System of operational restoration of a fresh resource of city reservoirs}

Urban ecosystems are made up of amazing interactions between living organisms and the abiotic environment, creating dynamic cycles of nutrients and energy. Human ability to displace and shape natural processes has improved, but the community continues to be dependent on ecosystem goods and services. The structure of ecosystem services clarifies the link between human well-being and ecosystem function. Ecosystem services are provided to the ecosystem to support the well-being of the community. Ecosystem service technology creates feedback that promotes both the ecosystem and the well-being of the community. In this context, it is clear that risks to natural resources such as soils and water have direct consequences for the community.

The research of replenishing the city's water balance is important, especially in the southern regions of Ukraine, where droughts disrupt the stability of processes and lead to social tension in the community.

Materials and methods of research. Hydrological studies and mathematical searches of such scientists as Prandtl D., Hosokava T., Ivasaki M., Ryabenko O.A., Tshai A.A., Epoyan S.M., Pantelyat G.S., Malko V.G., Kravchuk SM, Stolberg FZ, Karaghaur AS. Traditionally, hydrological measurements are conducted in natural conditions, and the authors propose the use of manmade flows to improve the energy efficiency of the water supply system.

Purpose and tasks. This work was performed in accordance with the requirements of reliability of water supply systems and ensuring the sustainability of economic development of cities. The requirements for ensuring the sustainability of freshwater development of the Integrated Water Resources Management program have been taken into account.

Research results. The structure of ecosystem services is a tool that can be used within the framework of strategic management of urban water supply and regulation of river basins. The tool helps regulators assess land uses and measures to reduce or prohibit man-made impact on community development. The ecosystem services approach does not involve monetary valuation, but by creating constraints, it extends the tools available to the regulator [11]. Discussing the consequences of man-made scenarios by different groups of experts and stakeholders may be sufficient to find compromises in different land use scenarios.

Investigating the risks of a reservoir imbalance is important for understanding the boundaries of the technological scheme and for identifying tools for stabilizing the city's basin. When released, the water undergoes local cavitation purification and, if necessary, chemical intervention to adjust the $\mathrm{pH}$ (industrial areas) (Table 1).

Conclusions. The paper classifies industrial and agricultural waste by the feasibility of restoration. The study of impregnation of different types of soils (from 1,11 to 0,05 cm/hour) was performed to feed the agrarian zones with conditioned re-water. The system of restoration of repeated waters which compensates to $32 \%$ of unbalance of a water basin is developed. 
«Системні технології» 4 (129) 2020 «System technologies»

Назаренко Алексей Николаевич - Доцент кафедры СПУП, Национальный университет «Запорожская политехника».

Доненко Василий Іванович - Профессор кафедры СПУП, Национальный университет «Запорожская политехника».

Назаренко Ирина Анатолиевна - Доцент кафедры ТГЕ ИИ, Запорожский Национальный університет.

Назаренко Олексій Миколайович - Доцент кафедри БВУП, Національний університет «Запорізька політехніка».

Доненко Василь Іванович - Професор кафедри БВУП, Національний університет «Запорізька політехніка».

Назаренко Ірина Анатоліївна - Доцент кафедри ТГЕ II, Запорізький Національний університет.

Nazarenko Oleksiy - PhD Building department, project management, National university «Zaporizhzhya politechnica».

Donenko Vasyl - Head of Building department, project management, National university «Zaporizhzhya politechnica».

Nazarenko Iryna - PhD Heat and gydro energy department Engineer Institute, Zaporozhye National University. 